\title{
Doris Stolberg
}

\section{Positioning by naming: Constructing group affiliation in a colonial setting}

\begin{abstract}
Defining groups and affiliating the self and the other with specific social categories is an important part of constructing a colonial conceptualization of societies. Many written documents from the colonial period attest to this practice. The current paper focuses on missionaries' ways of positioning themselves and others within the colonial context. The German speaking Rheinische Missionsgesellschaft (RMG, Rhenish Mission Society) established mission stations in the Astrolabe Bay area of New Guinea, an area that was under German domination between 1884 and 1914. The paper analyzes how RMG missionaries, by means of language, construct, define, and position different population groups, and it investigates what patterns emerge from these language practices.
\end{abstract}

Keywords: colonial group construction, positioning of self and other, genericity, stereotyping, mission societies

\section{Introduction}

Colonialism ${ }^{1}$ is founded, in large parts, on the construction of ideology-based borders between humans (cf. Anderson 1983). As a result, colonized people are not only geographically located outside of the colonial metropole ${ }^{2}$ but also, from a colonial viewpoint, positioned in specific spaces of a constructed socio-cultural landscape (cf. Spivak 1985). Such spaces, and the borders separating them, are crucially established through language and patterns of language use.

Conceptualizing people as inherently divided into groups that colonize and those that are (to be) colonized is an important part of justifying imperial colonialism (Said 1978). This conception is documented historically on a general level as well as with respect to specific local and small-scale interactions. It is reflected,

1 Colonialism, as a term, is used here to refer to the modern imperial colonialism of the European colonial period, starting with the 15 th century, and more specifically to German colonialism of the 19th and 20th century.

2 The term metropole refers to the homeland of the colonizing power.

Doris Stolberg, Institut für Deutsche Sprache, Abt. Lexik, R 5, 6-13, 68161 Mannheim, Germany. E-Mail: stolberg@ids-mannheim.de 
for example, in the communication of expatriate missionaries working in colonized areas and in the way groups are constructed in the missionaries' writings.

The current paper is based on historical documents from the Rheinische Missionsgesellschaft (RMG, Rhenish Mission Society), a German mission society that was active in colonial New Guinea between 1887 and 1932. Special attention is paid to documents from the period of German colonial rule, that is, 1887 to 1914. The paper investigates what groups are identified in these documents, and how they are addressed, referred to, or positioned.

The following section offers information on the relevant historical background. Next, the data are presented, framed theoretically, and analyzed. The paper ends with a summary of the findings and some considerations on discursive group construction in a colonial setting.

\section{The colonial setting}

During the second half of the 19th century, Germany assumed colonial dominance over several areas in Africa and Oceania. This paper centers on the South Pacific. Between 1884 and 1900, the northeastern part of New Guinea, the Bismarck Archipelago, the northern Solomon Islands, the Marshall Islands, Nauru, the Mariana Islands (except for Guam), the Caroline and Palau Islands, and (Western) Samoa became colonies of the German Empire. German colonial rule lasted until 1914 (de iure until 1919) when, with the beginning of WW I, the colonies were taken over by Australia, Japan, or New Zealand.

Christianizing the colonized population, and transmitting values of European culture, was considered an important part of exerting colonial power and carrying out the so-called 'mission civilisatrice", the civilizing mission the colonizers claimed to pursue within the colonial scheme of power. Therefore, the German government arranged for, or permitted, various mission societies to become active in the colonies. One of them was the RMG, a mission society already active in southern Africa since 1829. In 1885, the German government asked the RMG to set up the Protestant mission work in German New Guinea (Bade 1987: 62). The first RMG missionaries arrived in the Astrolabe Bay area (New Guinea) in 1887, and the RMG remained active in this region until 1932 when their mission area was transferred to the American Protestant mission.

3 This term is originally linked to French colonialism (cf. Conklin 1998, Costantini 2008), but as a concept, it is applicable to other colonial powers as well. 
Until 1900, the German Empire was represented in New Guinea by a German trading company, the New Guinea Company (N.G.C.). Since the RMG had been sent out by the German government, they were obligated to cooperate to a certain extent with the agents of the N.G.C. and to provide services as interpreters and mediators between the German staff (of the N.G.C. and, later, of the German government) and the local population (cf. Bade 1987). Several of the early mission stations were located in the vicinity of N.G.C. stations, a result of the requirement to have mission station locations approved by the N.G.C. (Bade 1987: 64). Especially Friedrich-Wilhelmshafen (Madang) is mentioned as a harbor town in close vicinity to several of the early RMG stations where not only missionaries but also the local population came into contact with a life style that the missionaries did not approve of (e.g., RMG 3.002-1 Nobonob; RMG 3.003-1 Ragetta).

Besides German officials and staff (N.G.C. and governmental), two other groups of expatriates were located close to the RMG mission area in New Guinea. These are the Societas Verbi Divini (SVD, Divine Word Society), a Catholic mission society, and the Neuendettelsauer Mission (NM, Neuendettelsau Mission Society), a Protestant mission society. The SVD had their mission area northwest of the RMG, bordering on the RMG area in the north of the Astrolabe Bay (cf. Loeffen 1991). The NM was located further east around the Huon Bay, so they had no shared border with the RMG but, as another Protestant mission, interacted and cooperated with the RMG to some degree.

During the colonial period, conflicts arose from the differing understanding the government and the missions had of the missions' role in the colonial setting. From the missions' perspective, it was their role to Christianize the local population, to spread European and Christian values and education, and to do so in the addressees' native languages, if possible. The government's expectation, in contrast, was that the mission societies provided education to the local population at low cost (for the government), to produce trained and acculturated local workers (by spreading European values and acceptance of the colonial order), and to disseminate knowledge of the German language by teaching it in school (cf. Adick \& Mehnert 2001). While there were some parallels in these goals, there were also obvious areas of tension.

Mission societies were thus colonial agents who contributed to the shaping of social structures under colonial conditions. One way of doing so was the missionaries' constructing groups and group membership in their writings that reflected preconceived notions of a colonial socio-cultural landscape. 


\section{Theoretical aspects of group reference}

This paper investigates different patterns of group reference from a formal and functional perspective, analyzing the linguistic means of group conceptualization and their applications in positioning the self and the other in a hierarchized structure of center and periphery. Among the linguistic options for constructing groups and group membership are exogenous group naming, that is, the introduction and application of exonyms (cf., e.g., Harder 2008), person stereotypes and their linguistic expressions (cf. Pümpel-Mader 2010), the use of genericity to assert group-defining characteristics, at the morphological-lexical and the syntactic level (cf. SchmidtBrücken 2018), and discursive group characterizations by means of discursive descriptions of events (related to textual genericity, cf. Schmidt-Brücken 2018: 47). All of these strategies can be found in the analyzed data.

One of the functions of conceptualizing group membership is identity work by positioning the self relative to others. While positioning theory is usually applied in conversational analysis and to face-to-face interactions, it can also offer some insights regarding (historical) written group reference. In the following, some central aspects of positioning theory are outlined. Further, two types of generalizing language use, namely genericity and stereotyping, are delineated, and it is indicated what linguistic forms and patterns can be applied to these ends.

\subsection{Positioning theory}

Positioning theory is an approach to interactive identity work that is originally based in social and cognitive psychology (Harré \& van Langenhove 1999, Harré et al. 2009). It refers to discourse strategies that participants of an interaction use in order to mark identity aspects they wish to present or enact. LuciusHoene \& Deppermann (2004: 171) note that positionings are not performed by one specific class of speech acts only. ${ }^{4}$ Positioning is a function of interactive language-based practices; it is not tied to a specific form (Lucius-Hoene \& Deppermann 2004: 171). This theoretical approach has been applied in linguistics research to such areas as discourse studies, conversation analysis, and language and identity studies (cf. Harré \& Moghaddam 2003, Lucius-Hoene \& Deppermann 2004, Schulze et al. 2008) as well as to postcolonial studies (for example, Aberdeen 2003).

\footnotetext{
4 "Positionierungen werden nicht mit einer bestimmten Klasse von sprachlichen Akten vollzogen” (Lucius-Hoene \& Deppermann 2004: 171).
} 
Harre et al. (2009) emphasize that with positioning the self and the other within a social space "a framework of rights and duties" (Harré et al. 2009: 6) is called up. This connection is obvious in the missionaries' writings, and the interaction between self-positioning and assuming certain duties becomes clear when seen from the perspective of positioning theory: Missionaries are convinced of their Christian-European duties and their being responsible for the bettering of the situation of those who are perceived to be not at the same level of understanding and 'development' as they themselves are. That is, from positioning themselves as 'saviors of souls', as doctors, artisans, helpers in various ways (cf. Helmich 1905) and as owners of material goods that are difficult or costly to acquire, they derive the duty to help and support the local population in achieving presumably higher levels of moral standing, and to provide (or withhold, for assumed educational purposes) material goods. They are convinced of these duties and of their ability to shoulder them; as a prerequisite and as a result, they position themselves in a dominant and superior position.

Positioning theory has been applied to narrative identity work and to spoken language interaction, among other things. In this paper, I probe its applicability to written data. The missionaries' texts can be seen as one part of an interaction, where the other side is only implicitly present. Accordingly, there is no information on whether the missionaries' positionings of the self and others were accepted by the intended addressees (usually in-group members) or by third parties that are referred to in these texts (such as other expatriate groups or the local population). While there is no direct evidence of negotiating positions, some texts indicate selective re-positionings that are likely to have been triggered by such negotiations (e.g., Helmich 1905).

It should be noted that this paper does not attempt to discuss the different roles and positions the agents took and negotiated. It is concerned with naming and group reference as a mechanism for constructing a social reality from a certain perspective, and it looks at specific linguistic means that are employed in this process.

\subsection{Linguistic means of constructing groups and group membership}

Different linguistic strategies can be employed to express the concept of specific groups and to place group boundaries within the constructed socio-cultural landscape. Among these strategies are genericity, stereotyping, and the use of exonyms. 


\subsubsection{Genericity}

Generic language use makes implicit assertions about people, conditions, concepts, etc. (cf. Schmidt-Brücken 2015, 2018). Genericity can be invoked by different linguistic means, that is, there is no stable correlation between specific linguistic forms and the expression of genericity. From a functional perspective, generic language use is often employed to affirm shared attitudes and perceived certainties.

Generic language use in colonial contexts can be localized in three different linguistic areas: textual genericity, syntactic genericity, and morphologicallexical genericity (Schmidt-Brücken 2018: 66). Textual genericity is created within the narrative or discursive treatment of a topic, an event, or an activity. Different syntactic means can be used to establish genericity, such as generic noun phrases, the assignment of specific semantic roles (e.g., patient), the use of adverbials, or, as a strategy to reclassify entities, the use of predicative constructions. Morphological-lexical genericity includes two aspects, namely, the use of collective derivational morphemes, and the pragmatic contribution to meaning via the usage of specific words. In addition, part of speech, number and the semantic category of a chosen word all interact with world knowledge (Schmidt-Brücken 2018). For example, the difference between the specific use of der Bezirksamtmann ('the county commissioner') and the generic use of der Papua ('the Papuan') in the missionaries' writings does not rest on a morphological differentiation but on contextual and world knowledge.

\subsubsection{Stereotyping}

The cognitive purpose of stereotyping can be summarized as providing an efficient way of handling information by reducing complexity. Similar to the encoding of genericity, stereotyping does not depend on specific linguistic means. There are, however, characteristic ways of encoding stereotypes, such as the use of main clauses or of the generic present, representing generalization and atemporality (Pümpel-Mader 2010). While there are differences between generic language use and stereotyping, both imply the general validity of the summarizing, and often simplifying, propositions that are made. According to Pümpel-Mader (2010: 424), stereotypes include two constituting elements: a social category (the carrier of a stereotype), and a quality or behavior (the feature) that is identified as typically 
belonging to or being part of the carrier. ${ }^{5}$ Terminologically, a distinction has to be made between the stereotype expression, that is, the verbal, figurative, or visual form of the sign, and the conceptual structure of stereotype that is represented by the stereotype expression (Pümpel-Mader 2010: 423). Four patterns of textualizing stereotypes can be identified: a descriptive, narrative, explicative, and argumentative pattern (Pümpel-Mader 2010: 329ff.). In addition, cognitive strategies (e.g., metonymy and synecdoche, such as naming the living environment instead of the persons) are frequent in stereotype expressions (Pümpel-Mader 2010: 425). These patterns show some overlap with the ways genericity is expressed. Both ways of generalizing language use depend on contextual cues that, in sum, contribute to the production of generalizations.

\subsubsection{Exonyms}

In the colonial context, place names/toponyms are often exonyms assigned by members of the colonial powers, and they are employed to demonstrate colonial dominance toward the colonized population as well as to other colonial powers (cf., for example, Stolz \& Warnke 2015, 2018; Engelberg \& Stolz 2016; Iturrioz Leza 2008; Schöner 2018). Exonyms, that is, names given from an external perspective, by a non-group member or an exogenous person, are frequently place names (Harder 2008) but there are also exonyms of people(s) or languages. In the current paper, the main attention is on group designations that are intended to structure and stratify communities into entities in accordance with exogenous cultural perceptions and expectations that is, not on exonyms in a narrower sense. One example of such conceptual structuring is that only with the advent of missionaries and the beginning of Christianization in New Guinea, it became meaningful to speak of pagans and to contrast them with Christians. The example also hints at the social repercussions of exogenous group conceptualizations. In this respect, exogenous group reference, especially in colonial settings, contains parallels to the application of exonyms; in both cases, exogenous concepts (social, geographical, etc.) are imposed on local groups and conditions.

5 "Die Festlegung des Stereotyps auf die beiden Elemente 'soziale Kategorie' (Träger) und 'Eigenschaft' bzw. 'Verhaltensweise' (Merkmal) sollte zur Präzisierung des Begriffs Stereotyp einen Beitrag leisten” (Pümpel-Mader 2010: 424). 


\section{The data and their contextualization}

The materials discussed in this paper are kept by the archives of the Vereinte Evangelische Mission (VEM = UEM/United Evangelical Mission), the successor organization of the RMG in Wuppertal (Germany). ${ }^{6}$ They consist of station reports from the early 1930s, reporting on the previous development and the contemporary situation of different mission stations; letters between missionaries (19121914); and a small number of other texts, mainly manuscripts relating to language matters and to the interaction with the local population. The large majority of these texts are written in German. ' While the main focus is on data from the German colonial period, a number of more recent texts, in particular station reports, were included because they contain information relevant for the colonial period.

The documents record the main activities of the RMG in the Astrolabe Bay, such as the foundation of new mission stations, staff decisions, interactions with other mission societies, and with the N.G.C. Beyond this factual information, the texts express attitudes towards different groups of colonial agents.

None of the analyzed texts were (intended to be) published or otherwise circulated outside of the mission society. They were part of the discourse within the mission society, and they were aimed at members of this community. Nonmissionary expatriates and the local population in the mission area in New Guinea are unlikely to have been part of the intended audience. The documents testify to the effort of coping with a previously unencountered social structure and linguistic diversity. Social categorizations are employed to structure this new social environment conceptually; these conceptualizations from an exogenous perspective, in turn, shape the way the environment is perceived.

\section{Group references in RMG documents}

At the level of discourse, different groups are distinguished that can again be grouped together into higher-level categories. The conceptualization of these

6 The RMG and another evangelical mission society, the Bethel Mission, merged in 1971 to form the Vereinte Evangelische Mission (VEM). - I wish to thank the archive of the Vereinte Evangelische Mission (VEM) in Wuppertal (Germany) and especially Wolfgang Apelt for his generous help in making these documents available to me.

7 There is only one exception: Hannemann-1 is in English. A complete list of the materials used can be found in the reference section. 
higher categories is implicit in the texts but their understanding is crucial for assessing where the missionaries positioned themselves and others in the colonial social landscape. The data indicate further, explicitly and implicitly, that these higher-level divisions are linked to values of membership and moral acceptability. The higher-level categories include expatriate groups, subdivided into mission societies and other expatriate groups, and the local population.

\section{Expatriate groups}

Mission societies:

- the Rhenish Mission Society (RMG) (Protestant; $G^{8}$ )

- other Protestant missions: Neuendettelsauer Mission (G), Methodists ( $\left.E^{9}\right)$

- Catholic mission: Societas Verbi Divini (SVD) (G)

Other expatriate groups:

- New Guinea Company

- German colonial government

- traders, planters

\section{Local population}

- Papuans, Melanesians

- Christians vs. non-Christians

A differentiating treatment can be observed within the category of mission societies, namely, with respect to denomination: While the Protestant missions are mentioned and named in a neutral manner, the Catholic mission is constructed as a rival or competitor, and interactions with the Catholics are described as being conflict-ridden (cf. below).

In the data, a number of strategies and linguistic means are employed to express group distinctions. In the following sections, examples of group reference are given to provide an overview of the range of usages. ${ }^{10}$

The first section includes expressions that are used to refer to the RMG and its members. These expressions can be pronominal, possessive (indicating a strong identification with the RMG), or referring to the position or rank of individuals.

\footnotetext{
$8 \mathrm{G}=$ German speaking.
}

$9 \mathrm{E}=$ English speaking.

10 All translations from German originals are mine (D.S.). They are intended to reflect the German originals as closely as possible and are therefore not always idiomatic English translations. - Please note that Hannemann-1 is written in English, so there are no German versions for quotes from this source. 


\section{Reference to self}

- die Rheinische Mission 'the Rhenish Mission [Society]'

pronominal (1st person):

- wir 'we'

possessive (1st person):

- unsere Mission 'our mission [society]'

rank/function (in increasing specificity):

- Missionare/der Missionar 'missionaries/the missionary'

- Bruder/Schwester 'brother/sister' (a common way of referring to members of a religious order)

- Laienbruder, Baubruder, Pflanzungsbruder etc. "lay brother, building brother, plantation brother' (referring to lay members of the mission who fulfill special functions)

- der Präses 'the president [of the RMG]'

The options for self-reference demonstrate a well-differentiated range of expressions, including a general reference to the institution as well as the specification of a singular function. Morphologically, generic singular or plural forms are rarely used (only with der Missionar 'the missionary'). Overall, there is little genericity or stereotyping to be found in the expressions referring to (members of) the RMG.

\section{Other mission societies}

- Protestant mission societies

- die Neuendettelsauer 'the Neuendettelsau [people/missionaries]'

- die Methodisten im Archipel 'the Methodists in the [Bismarck] Archipelago'

Other Protestant mission societies are only referred to as groups, with generic plural marking, characterized by their affiliation (and location). No individual reference is made to members of these groups.

- The Catholic mission society

All of these expressions refer primarily to the SVD, the Catholic mission society whose area bordered on that of the RMG. Some neutral expressions are used, denoting the institution rather than individuals:

- die katholische Mission 'the Catholic mission'

- die römische Mission 'the Roman mission'

Already the reference römisch, however, includes a stereotypical expression that hints at a more conflict-laden relationship by referring to a place instead of 
a denomination. The next examples indicate the competition that was felt between the two denominations. Expressions such as Römlinge and Rom point towards the conflicts of the 1870 s Kulturkampf ${ }^{11}$ between the Catholic Church and the German nation state.

- die römische Konkurrenz 'the Roman competition'

- Römlinge 'Rome-lings' (a derogatory term for Catholics that originated in the 18th century ${ }^{12}$ and was also employed in connection with the Kulturkampf)

- Rom 'Rome' (a doubly-metonymic reference, to the place where the head of the Catholic church (i.e., the Pope) resides, the place and the Pope both being metonyms for the Catholic mission society in this case)

In a discursive description, the two groups are depicted as hostile parties fighting over a shared border:

- [D]ie (wohl im Jahre 1915) zwischen Br. Hanke/Blum und dem Pater Präfekt vereinbarte Grenze (S.W.Linie) wurde nie inne gehalten und das Protokoll von den Kath. nie unterschrieben. Sie bestanden auf der S.S.W. Linie, die aber von uns niemals zugestanden wurde. (RMG 3.002-1 Nobonob) 'The border line that was agreed upon (apparently in 1915) between Br[others] Hanke/Blum and the Pater Prefect (S[outh].W[est]. line) was never kept and the protocol was never signed [i.e., ratified] by the Catholics. They insisted on the S[outh].S[outh].W[est]. line which, however, was never accepted by us.'

In addition, it is implied that turning to the Catholics may be even worse than forsaking Christian values. This attitude highlights once more the strongly felt rivalry between the RMG missionaries and the Catholic mission.

- manche sind in der Versuchung nicht bestanden, etliche neigen gar zu den Katholiken (RMG 3.003-1 Ragetta) 'some have not resisted the temptation, several even tend towards the Catholics'

Hannemann-1, in the early 1930s, strikes a more conciliatory note. While still using a generic plural, he emphasizes the connecting rather than the dividing aspects by using a possessive (1st person) pronoun and emphasizing the regional vicinity of the Catholic mission. This may well have to do with the

11 Kulturkampf (with respect to Prussia and Germany) refers to the period of strong political conflict between the rising nation state and the Catholic Church (cf. Orosz 2011 for repercussions of the Kulturkampf in the German colonial area in Cameroon between 1885 and 1914).

12 Cf. Deutsches Wörterbuch von Jacob Grimm und Wilhelm Grimm, vol. 14, col. 1161 (http://www.woerterbuchnetz.de/DWB?bookref=14,1161,1). 
changed political climate after WW I and the end of German colonialism, and also with the increased temporal distance to Kulturkampf-related conflicts.

- our neighbors, the Romanists

- the Catholics

\section{Other expatriate groups: N.G.C., government, traders/planters}

Non-missionary expatriates are referred to in more neutral terms. There is some indication of hostile attitudes (missionsfeindlich "hostile towards the mission(s)') but it is not as prevalent as with respect to the Catholic mission. Social stratification within this group is marked by naming the function or rank of individuals, something that is also found regarding the RMG (the self) while it is not done with respect to the Catholic mission.

- Europäer 'the Europeans'

- die Weissen 'the white'

officials:

- die Beamten der N.G.C. 'the officials of the N.G.C.'

- Vertreter der N.G.C. und sonstige Herren 'representatives/officials of the N.G.C. and other gentlemen'

- missionsfeindliche Pflanzer und (einz.) Regierungsbeamte 'planters and (few) government officials who are against (the) missions'

- some planters and officials of the government

- die Herren der Deputation 'the gentlemen of the deputation'

- Die Nähe der Pflanzungsstationen der Neu Guinea Comp. in Stephansort und Erima übte keine guten Einflüsse aus und brachte die Christen in Gefahr (RMG 2.997-1 Bogadjim) 'The close vicinity of the New Guinea Company's plantation stations in Stephansort and Erima [sc. to the RMG mission stations] did not exert a positive influence [sc. on the mission's Christians] and endangered the Christians'

rank/function (individuals):

- der Admiral mit seinem Offiziercorps 'the admiral with his officer corps'

- der Bezirksamtmann 'the county commissioner'

- der Gouverneur/Exzellenz 'the governor/Excellency'

Within stereotype expressions, features can be linked implicitly to their carriers: The areal adjacency to the Pflanzungsstationen ('plantation stations', as a synecdoche for the N.G.C. representatives and their staff) - the syntactic subject of the clause - is blamed for a negative impact on local Christians. The (implied) actual carrier of this feature is, of course, the members of the N.G.C. and their lifestyle. 


\section{Local population}

- generic reference

plural nouns

- die Leute 'the people'

- die Eingeborenen 'the natives/the indigenous [people]'

- die Bergleute 'the mountain people'

- die Papua 'the Papuans'

- unsere Papua 'our Papuans'

- die Christen 'the Christians'

- die heid. Bergbewohner 'the pagan mountain dwellers'

singular nouns

- der Eingeborene 'the native/the indigenous [person]'

- der Papua 'the Papuan'

- der Bergchrist 'the mountain Christian' [i.e., the Christian living in the mountain area]

- der erwachsene Tamol 'the adult Tamol' (Helmich 1905)

- (Tamol is the Bel/Gedaged word for 'person/human being' or 'man/ male'; cf. ABVD word list for Gedaged, entries no. 53, 54 and Stolberg 2017: 76)

When discussing translation problems, Helmich (1907) emphasizes that social and economic structures in New Guinea are quite different from those described in Biblical texts. He maintains that these differences pose a problem for translating the texts in a comprehensible way. ${ }^{13}$ The examples he offers contain generic propositions such as:

- Der Papua pflanzt, aber er säet nicht. (Helmich 1907: 124) 'The Papuan plants [crops], but he does not sow.'

- Die Eingeb. flicken weder Kleider, noch bringen sie ihr Geld in die Wechselbank. Er (der Eingeb.) kann auch das Licht nicht unter den Scheffel stellen. (Helmich 1907: 124) 'The natives neither mend their clothes nor do they take their money to a bank. He (the native) cannot hide his light under a bushel, either.'

- Wenn man hier an der Küste einen als dumm und unerfahren, ungeschickt bezeichnen will, dann sagt man: du bist wohl aus den Bergen, aus dem Hinterlande [...] (Helmich 1907: 133) 'If you want to refer to someone as stu-

13 What is curiously absent from his remarks is any expression of awareness that the Biblical texts also had to be adapted culturally when they were translated into German from the original Hebrew resp. Greek. 
pid and unexperienced, clumsy, down here at the coast you say: you seem to be from the mountains, from the back country [...]'

- [...] daß man diese Bezeichnung für die Nichtchristen nehmen solle [...] ist [...] aber nicht gut möglich - wie soll dann der Bergchrist die heid. Bergbewohner benennen. Außerdem muß es für die Bergleute verletzend sein. (Helmich 1907: 133 cont.) 'to take this label to identify non-Christians is not feasible - how should the mountain Christian refer to the heathen mountain dwellers. In addition, it must be offensive for the mountain people.'

These remarks, while referring to groups of local people in a generic manner, indicate a more differentiated view, including a reflection on sensitive language use. Comments as these converge with Engelberg's (2014: 322) observations regarding an increasing recognition of the complexities of local languages among those expatriates who acquired them. Similarly, missionaries who worked locally developed awareness for the social structures around them.

- specific reference

With respect to the local population in the Astrolabe Bay, individual recognition (by name and rank/function) is reserved for Christians only.

- 4 samoanische Gehülfenpaare (eingetroffen [named individually]) [...] alle vier Paare “4 Samoan helper couples (arrived [names are listed]) [...] all four couples'

- Häuptling Mul [...] Ältester (treuer Christ und Führer) 'Chief Mul [...] Elder (faithful Christian and leader)'

- Samoaner Taeao (mit Frau und einem Kind) 'the Samoan, Taeao (with wife and one child)'

- Lehrer Madom 'the teacher Madom'

- Gemeindeleiter Madoi 'the congregation leader Madoi'

\section{Local population: Stereotype constructions with carrier + feature}

For a number of group and generic references, the pattern Pümpel-Mader (2010: 424) identified can be observed. The carrier + feature construction appears in attributive constructions as well as in predicative ones in the data. The following examples show how it is employed to assign intellectual and psychological features to different groups (mental feature stereotypes) as well as to position local Christians within a paternalistically defined caretaking relationship ((im)maturity stereotypes).

Mental feature stereotypes:

- die schwerfälligen Bongu 'the cumbersome Bongu [people]'

- die trägen stolzen Bodadjim 'the lazy, haughty Bogadjim [people]'

- die unzuverlässigen Keku-Inländer 'the unreliable Keku inland people' 
- the supposed superiority of the inland people over against the lethargic and lazy Melanesians has been overemphasized

- the Papuan - a bit more sequacious and lively than the Melanesian on account of the cooler climate in the hills

- the coastal man - more grave, more deliberating, and intellectually a little bit above the inlander

(Im)maturity stereotypes:

- die Eingeborenen arbeiten schon ziemlich selbständig darin [i.e., in the mission station's store] 'the natives already work fairly independently [in the mission station's store]'

- Gemeinde von Br. Schütz gut erzogen 'congregation well trained by Br[other] Schütz'

- selbständige Reisen von Christen unter Führung der Ältesten 'independent travels of Christians under the guidance of the elders'

- bisher unberührte Heiden 'heathens who were untouched [by Christianity] until now'

- die Christen (zumeist standhaft, einige ließen sich ins Garn locken) 'the Christians (mostly steadfast, some let themselves be lured into temptation)'

The latter descriptions, in particular, construct the stereotype that local/converted Christians are in a (possibly vulnerable) state of development - they have to be trained, they are susceptible to temptations, and they are not expected to act without guidance.

\section{Metaphor: 'natives are children'}

In Helmich (1905), the extensive use of educational vocabulary is noteworthy (e.g., erziehen 'educate', groß ziehen 'raise', verziehen 'spoil', verwöhnen 'pamper', strafen 'punish'). Here, local people, adults and children alike, are implicitly and also explicitly equated with children, indicating a strong conceptual asymmetry between the locals and the missionaries from the perspective of this missionary.

- Unsere Eingb. sind Kinder, und zwar nicht Kinder an der Bosheit, wohl aber am Verständnis. Es sind somit meist recht ungezogene Kinder, die einer straffen, aber doch auch wieder liebevollen Erziehung bedürfen. 'Our natives are children, not children in terms of maliciousness but in understanding. Thus, they are mostly rather naughty children who need a strict but also loving education/upbringing.'

- Allein es gilt auch hier die Erziehung der Leute im Auge zu behalten. Wir dürfen kein Bettelvolk groß ziehen. 'However, also here it is important to keep an eye on the education/upbringing of the people. We must not raise a people of peddlers.' 
- Nun habe ich schon oben darauf hingewiesen, daß wir es im allgemeinen mit ungezogenen und unverständigen Kindern zu tun haben, die erzogen werden müssen. 'I mentioned above already that, in general, we are dealing with naughty and ignorant children who have to be educated.'

A similar asymmetry is reflected in the depiction of spiritual relationships where the relationship between God and the missionaries is compared with that between the missionary and the local people:

- Der Missionar tritt als ein Zeuge des Heilandes und als ein Träger des Christentums unter die Heiden 'The missionary steps forward among the heathens as a witness of the Savior and as a carrier of Christianity'

- Je demütiger wir erkennen, welch unaussprechliche Geduld der Herr doch auch mit uns noch Tag um Tag haben muß, desto besser werden wir auch an unsern Eingeb. Geduld üben können. 'The more we humbly recognize how inexpressibly patient the Lord has to be even with us every day the better we will be able to exercise patience towards our natives.'

With a generic singular noun as the carrier, adjectives work as features in stereotypical descriptions of local people. In some cases, such descriptions are contrasted with similarly stereotypical ones of the in-group, referred to as 'we' or 'we Europeans'. While such contrasts function well as positioning devices, the examples also show that there is no clear-cut correlation between positive and negative evaluations as relating to either the in-group or the out-group.

- Der Eingeb., schlau und pfiffig, wo es sich um seinen Vorteil handelt 'the native, clever and smart when his own advantage is concerned'

- Im allgemeinen hat der erwachsene Tamol ein würdiges Auftreten. 'In general, the adult tamol has a dignified appearance.'

- Der Eingeb. ist träge, oft bodenlos gleichgültig und zuweilen schwer von Begriff. Wir unserseits [sic] sind meist nervös, und infolgedessen schnell aufgeregt und leicht gereizt. 'The native is lethargic, often infinitely indifferent, and occasionally slow-witted. We, on our part, are often nervous and consequently quickly excited and easily irritated.'

- Wir Europäer sind im allgemeinen an rasches Entschließen und Handeln gewöhnt. [...] Anders ist es mit unserm Papua. 'We Europeans are, in general, used to decide and act quickly. [...] This is different with respect to our Papuan.'

This last example illustrates well what Schmidt-Brücken (2018) refers to as effects of syntactic genericity. While wir Europäer constitutes the subject in the nominative at the beginning of the clause, unser[...] Papua is not only referred 
to in (generic) singular and used with a possessive pronoun, but it also appears at the end of the clause (in a contrastive chiasm position to wir Europäer) and is embedded syntactically as the dative noun phrase within a prepositional phrase. The contrastive positioning and the stereotypically framed differences in agentivity are thus underpinned by the syntactic structure.

\section{Narrative group characterization}

As a final example, the narrative, or textual (Schmidt-Brücken 2018), construction of groups and group membership is represented below. The excerpt from a letter (of 1913) by the missionary Hanke to superintendent (Missionsinspektor) Kriele contains not only explicit group references but shows how in a contrastively structured narrative these group references are contextualized from a colonial viewpoint (line and page breaks as in the original; emphasis added, D.S.).

Am 12. JULI hatte ich ganz ungesucht Gelegenheit vor dem Offiziercorps und einem Teil der Mannschaft Zeugnis abzulegen. Es starb ein Oberheizer evgl. Konfession. Da bat mich dann der Kommandant des Sch. Die [sic] Beerdigung zu übernehmen, was ich natürlich mit Freuden tat. Das Begräbnis war für die vielen Eingeborenen, die in Fr.W.H. waren, ein eindrucksvoller Anschauungsunterricht. Am Nachmittage dieses Tages war Parade. Es wurden 400 Mann Infanterie und von der Artillerie und den Maschinengewehrabteilungen 200 Mann ausgeschifft. Auf einem großen Rondell hatten an 1500 Eingeborene, die der Bezirksamtmann zu der Feier zusammengeholt hatte, Aufstellung gefunden. Auf dem das Rondell umgebenden Wege rückten dann die Kolonnen an. An der Spitze die Infanterie mit klingendem Spiel und aufgepflanztem Seitengewehr. Hinter ihr Artillerie und Maschinengewehrabteilungen. Was machten da unsere Papua für Augen! Das schien ja als wollte es gar kein Ende nehemen [sic]. Das ganze Rondell war schließlich umgeben von einer Mauer in Waffen starrender weißer Menschen. Die braunen Leutchen meinten, ihr letztes Stündlein sei gekommen. Endlich kam der Admiral, die Parade abzunehmen. Als nun die Kolonnen sich im Parademarsch in Bewegung setzten und die Umklam-

merung [page break]

allmählig [sic] sich löste, atmete alles auf. Ihr Leben lang werden die Papua dies Schauspiel nicht vergessen. (RMG 2.149-006 Hanke an Kriele, 1913-9-23) 'On the 12th of July I had the unexpected chance to testify [sc. my Christian faith] in front of the officer corps and part of the crew. An Oberheizer [a nautical rank] of Protestant faith had died. So the commander of the ship asked me to hold the funeral service, which I gladly agreed to do. The funeral was 
an impressive demonstrative object lesson for the many natives who were in Fr[iedrich-]W[ilhelms]h[afen]. In the afternoon of the same day, there was a parade. 400 infantrymen and 200 men from the artillery and the machine gun sections were disembarked. On a great rondel, around 1,500 natives whom the district officer had brought together had assembled for the ceremony. Along the way around the rondel, the troops advanced. They were headed by the infantry, approaching with ringing music and bayonet fixed. It was followed by the artillery and the machine gun sections. How our Papuans grew wide-eyed! This [parade] seemed to take no end. Eventually, all of the rondel was surrounded by a wall of white people bristling with weapons. The brown people [Leutchen, diminutive of Leute 'people', lit. 'little people'] were convinced that they should die. Finally, the admiral came to take the salute. As the troops began their march in review and the stranglehold slowly started to loosen, everybody breathed a sigh of relief. Never in their lives will the Papuans forget this spectacle.'

In this passage, several features can be identified that position different groups of agents within the reported setting. Early on, the term Anschauungsunterricht 'demonstrative object lesson' links to the child metaphor already mentioned above. Further, syntactic means are used to place the involved agents in different hierarchical positions: The district officer (Bezirksamtmann) is described as acting while the local population is the syntactic object (of the relative clause referring to the people's location on the rondel). In addition, reference is made to skin color (white vs. brown). While the colonizers are depicted almost as machinery (with detailed descriptions of weapons, no indication of emotions, and in possession of control: Umklammerung 'stranglehold'), the local population is termed in the diminutive (Leutchen) and described as expressing strong emotions of bewilderment (machten [...] Augen 'grew wide-eyed') and great fear (meinten, ihr letztes Stündlein sei gekommen 'were convinced that they should

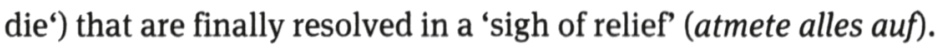

Interestingly, there is a change of perspective at one point, after Was machten da unsere Papua für Augen! 'How our Papuas grew wide-eyed!'. While this sentence still describes the situation from the viewpoint of the missionaryobserver, the following clause, Das schien ja als wollte es gar kein Ende nehmen, seems to intend to take the perspective of the Papuan people present, almost as if speaking for someone who cannot speak for himself (cf. Spivak 1988). This new perspective offers an interpretation of the (assumed) emotions of the Papuan participants. It is an interpretation, however, that cannot be checked against the Papuans' own perspective and experience. This constructed perspective is then framed as an instructional context (Ihr Leben lang [...] nicht vergessen 'nev- 
er in their lives [...] forget'), not only contrastively highlighting the power asymmetry between the colonizing power (here presented as military power) but also tying in with the metaphor of the local people as children that lack understanding and education.

\section{Results and discussion}

The examples from the data show how different language-based strategies are employed to construct group membership and to demarcate positions of the self and the other. Some of the social patterns that emerge from the implicit and explicit attributions made in the texts are considered here more closely.

The main division line between groups of people runs along the lines of local vs. expatriate. Group-internally, expatriates are distinguished according to rank level, with respect to denomination (Protestant/Catholic), and whether they are mission members or not. This last group (non-mission members) is heterogeneous, being defined ex negativo and including traders, administrative staff, sailors, etc.

The two groups (local vs. expatriate) are assigned different values, and the level of detail in reference to individuals diverges. The data indicate, however, that there is not just a line between the colonizers and the colonized: The RMG also positions itself with respect to other religious denominations and to nonchurch agents of the colonial metropole. Thus, these divisions result in a threeway group distinction: the in-group (self), the close out-group (other expatriates), and the distant out-group (the autochthonous population). While hierarchies of rank are named in both groups, the local as well as the expatriate population, the distinctions are more fine-grained for members of expatriate groups. Another difference is that positioning within the in-group is done by societal rank but not by local origin. The geographic origin of expatriates is never mentioned; in contrast, for the local population, explicit distinctions regarding regional provenance are made and linked with (stereotypical) personal characteristics (cf. the section on "Local population: Stereotype constructions with carrier + feature").

Within the group of local people, a crucial divide appears between Christians and non-Christians. Becoming Christian seems to offer the opportunity for the local, colonized population to cross borders and become, to a certain degree, in-group members of the RMG. This is reflected linguistically by a changed way of reference, that is, these persons are named individually (a form of reference usually reserved for expatriates) instead of generically or as groups. 
In sum, the societal patterns that emerge from the group references in the documents are as follows:

- Regarding expatriates, differentiated reference is made to the in-group as a whole (governmental as well as missionary) as well as to individual members of this group.

- Within the local population (i.e., the out-group), non-Christians are never referenced individually but always in generic and stereotypical terms.

- Local individuals are referred to only if they are Christians and are members of or cooperate with the RMG, but Christian out-group members are often referred to in a generalized way as well.

An aspect that is worth mentioning with regard to group conceptualization is the use of possessive adjectives in the data. It is also an example of one grammatical form serving different discursive functions. In general, possessive marking can be understood as being linked to identity and identification. The authors of the investigated texts position themselves as members of the RMG but also as Europeans and as 'whites'. The use of a 1st person plural possessive adjective can mark either one or all of these positionings as a point of reference.

There are two groups with whom the 1st person plural possessive adjective is used: the local population and the Catholic mission. From the context, it is clear that these two cases must be understood differently. In the case of unsere Papua 'our Papuans'/unsere Eingeborenen 'our natives', the possessive does not express in-group affiliation at eye level but on a hierarchical scale of assumed responsibility that is linked to superiority on the side of the writers, almost pointing in the direction of an actual possession. This type of in-group membership is marked by appropriation in the sense that the colonized people are not considered independent agents within the colonial structure. As the context indicates, they are rather seen as dependent and in need of guidance. In contrast, the use of the possessive adjective in our neighbors, the Romanists is, though formally the same, quite different in meaning. The RMG's relationship with the Catholic mission society changes over time from competition to affiliation, finally emphasizing geographical vicinity as a common ground. Thus, here the possessive adjective appears to reflect the assumption of (more or less) equal standing, expressing shared group membership rather than subjected group membership.

In general, the colonizers are depicted as dominant agents, and they figure as the point of reference for any judgment on the local population. It is not surprising, of course that documents from a mission archive, produced by members of this mission society, focus on expatriate mission members specifically and also on other expatriates (from the same homeland). By identifying differ- 
ent groups that are distinct from the in-group, an in-group identity is constructed and shaped through language use. This strategic use of language for creating group distinctions was probably not fully intentional. It resulted, however, in a stronger specification of the mission members' own group identity and in the creation of mental borderlines between group formations that were newly defined in this process.

\section{Concluding remarks}

The examples of group reference from the colonial missionary data indicate how human society can be structured conceptually by language means. The data also show, however, that the ability to exert this structuring power is not available to all agents. Being able to introduce and spread a new terminology is one example of agency in this respect. Missionaries are among the agents who had this power, for example when they translated Biblical texts that became reference points for the Christianized population. Another aspect of the assertive application of new (group) concepts is the matter of written vs. spoken language and the question of who documents their (own) language use. Again, missionaries were among those who recorded their language use and their considerations regarding language, translation, how to integrate foreign concepts into their own language use, and how to impose loanwords on other group's languages, denoting, for example, Christian concepts and values.

In a setting of power asymmetry such as colonialism, language use may have even more social consequences than in other contexts. Its influence is mediated by the function of specific language users (e.g., missionaries) and their ranking in the relevant social hierarchies. That is, societal position makes a difference for whose conceptualizations are preserved and may become dominant. Stereotyping, genericity, and exogenous attributions are used to position not only the language users themselves but also those they place within the colonial sociocultural landscape. Their group categorizations had broad repercussions in the colonial areas as well as in the homeland. Schmidt-Brücken (2018: 65) notes that the non-negated use of a word forces the presupposition that its denotatum actually exists. ${ }^{14}$ In this sense, referring to groups in specific ways is a claim to the existence of such groups and to their dividing characteristics.

14 “[...] dass unnegierter Wortgebrauch eine Existenzpräsupposition über das Denotat des Wortes erzwingt" (Schmidt-Brücken 2018: 65). 


\section{References}

\section{(a) Primary sources}

Archival material (Archive of the United Evangelical Mission (VEM), Wuppertal):

\section{Letters:}

- Hanke-2 = RMG 2.149-2 Hanke an Kriele, 1912-6-21 (letter)

- Hanke-4 = RMG 2.149-4 Hanke an Kriele, 1914-1-19 (letter)

- Hanke-5 = RMG 2.149-5 Hanke an Kriele, 1913-1-19 (letter)

- Hanke-6 = RMG 2.149-6 Hanke an Kriele, 1913-9-23 (letter)

- Hanke-7 = RMG 2.149-7 Hanke an Kriele, 1913-2-8 (letter)

- Hanke-8 = RMG 2.149-8 Hanke an Spiecker, 1914-1-13 (letter)

- Diehl-1 = RMG 2.154-1 Diehl, 1913-2-17 (letter)

\section{Information on RMG mission stations:}

- RMG 2.997-1 Bogadjim

- RMG 2.998-1 Bongu

- RMG 3.001-8 Neuguinea

- RMG 3.002-1 Nobonob

- RMG 3.003-1 Ragetta

\section{Other documents:}

- Sprachkonferenz = RMG 3.008-28: Anon. 1898. "Die 3. Sprachkonferenz/Sprachkonferenz in Bogadjim" [records of the mission language conference of 1898], pp. 98-102.

- Helmich 1905 = RMG 3.014a G/b 2 a: Heinrich Helmich. 1905. "Die Behandlung unserer Eingeborenen durch den Missionar im alltäglichen und persönlichen Verkehr/Konferenzreferat" [manuscript of a presentation held at a missionaries' meeting], pp. 67-80.

- Helmich 1907 = RMG 3.014a-9: Heinrich Helmich. 1907. "Die Bildung einer christlichen Terminologie in der Siar Sprache und die damit verbundenen Schwierigkeiten" [on developing a Christian terminology in Siar; manuscript of a presentation held at a missionaries' meeting], pp. 111-134

- Hannemann-1 = RMG 3.013-1: E[mil] F[riedrich] Hannemann [no date]. "A few statements in regard to the introduction of Ragetta as the universal language in our mission at Madang." [arguing for the introduction of Ragetta as the "universal" Lutheran mission language in the Astrolabe Bay area].

- Kleintitschen, [P.] August. 1906. Die Küstenbewohner der Gazellehalbinsel (Neupommern - deutsche Südsee) ihre Sitten und Gebräuche. Hiltrup: Herz-Jesu-Missionshaus. 


\section{(b) Monographs and articles}

Aberdeen, Lucinda. 2003. Positioning and postcolonial apologizing in Australia. In Rom Harré \& Fathali M. Moghaddam (eds.), The self and others: Positioning individuals and groups in personal, political, and cultural contexts, 189-196. Westport, CT: Praeger.

ABVD. Austronesian Basic Vocabulary Data base. Language: Gedaged. Source/Author: Robert Blust, from J. F. Mager. 1952. Gedaged-English Dictionary. Columbus, $\mathrm{OH}$ : Board of Foreign Missions of the American Lutheran Church, https://abvd.shh.mpg.de/austronesian/language.php?id=7\&sort=word_id (accessed 05 May 2018).

Adick, Christel \& Wolfgang Mehnert (unter Mitarbeit von Thea Christiani). 2001. Deutsche Missions- und Kolonialpädagogik in Dokumenten. Eine kommentierte Quellensammlung aus den Afrikabeständen deutschsprachiger Archive 1884-1914. Frankfurt a. M. u.a.: IKOVerl. für Interkulturelle Kommunikation.

Anderson, Benedict. 1983. Imagined communities: reflections on the origin and spread of nationalism. London: Verso.

Bade, Klaus J. 1987. Culture, cash and Christianity: The German colonial experience and the case of the Rhenish Mission in New Guinea. Pacific Studies 10(3). 53-71.

Conklin, Alice L. 1998. A Mission to Civilize: The Republican Idea of Empire in France and West Africa 1895-1930. Stanford: Stanford University Press.

Costantini, Dino. 2008. Mission civilisatrice. Le rôle de l'histoire coloniale dans la construction de l'identité politique française. Paris: La Découverte.

Deutsches Wörterbuch von Jacob Grimm und Wilhelm Grimm. http://dwb.uni-trier.de/de/. Engelberg, Stefan. 2014. Die deutsche Sprache und der Kolonialismus. In Heidrun Kämper, Peter Haslinger \& Thomas Raithel (eds.), Demokratiegeschichte als Zäsurgeschichte, 307332. Berlin \& Boston: De Gruyter Mouton.

Engelberg, Stefan \& Thomas Stolz. 2016. Einleitung: Namen und Kolonialismus. Beiträge zur Namenforschung 51(3/4). 269-277.

Harder, Kelsey B. 2008. Names in language contact: Exonyms. In Ernst Eichler, Gerold Hilty, Heinrich Löffler, Hugo Steger \& Ladislav Zgusta (eds.), Name studies. An international handbook of onomastics, vol. 2, 1012. Berlin \& New York: De Gruyter.

Harré, Rom \& Fathali M. Moghaddam (eds.). 2003. The self and others: Positioning individuals and groups in personal, political, and cultural contexts. Westport, СТ: Praeger.

Harré, Rom, Fathali M. Moghaddam, Tracey Pilkerton Cairnie, Daniel Rothbart \& Steven R. Sabat. 2009. Recent advances in positioning theory. Theory \& Psychology 19(1). 5-31. Harré, Rom \& Luk van Langenhove (eds.). 1999. Positioning theory. Oxford: Blackwell. Iturrioz Leza, Jose-Luis. 2008. Namen in kolonialen und postkolonialen Verhältnissen: Mesoamerika. In Ernst Eichler, Gerold Hilty, Heinrich Löffler, Hugo Steger \& Ladislav Zgusta (eds.), Name studies. An international handbook of onomastics, vol. 2, 1058-1064. Berlin \& New York: De Gruyter.

Loeffen, Volker. 1991. Die Rheinische Mission in Neu-Guinea 1886-1914. Unpublished M.A. Thesis. University of Duisburg.

Lucius-Hoene, Gabriele \& Arnulf Deppermann. 2004. Narrative Identität und Positionierung. Gesprächsforschung - Online-Zeitschrift zur verbalen Interaktion 5. 166-183. www.gespraechsforschung-0zs.de.

Orosz, Kenneth J. 2011. An African Kulturkampf: Religious conflict and language policy in German Cameroon, 1885-1914. Sociolinguistica 25. 81-93. 
Pümpel-Mader, Maria. 2010. Personenstereotype. Eine linguistische Untersuchung zu Form und Funktion von Stereotypen. Heidelberg: Winter.

Said, Edward W. 1978. Orientalism. New York, NY: Pantheon Books.

Schmidt-Brücken, Daniel. 2015. Verallgemeinerung im Diskurs: Generische Wissensindizierung in kolonialem Sprachgebrauch. München, Berlin \& Boston: De Gruyter Mouton.

Schmidt-Brücken, Daniel. 2018. Generizität. Sprachgebrauchsgeschichtliche und diskurslinguistische Aspekte kolonialer Kommunikation. In Birte Kellermeier-Rehbein, Matthias Schulz \& Doris Stolberg (eds.), Sprache und (Post)Kolonialismus. Linguistische und interdisziplinäre Aspekte, 41-69. Berlin \& Boston: De Gruyter Mouton.

Schöner, Mathias. 2018. Kulturmission oder Herrschaftssymbolik? Zur Verbreitung deutscher Zeichensysteme in der „Musterkolonie“ Tsingtau. In Birte Kellermeier-Rehbein, Matthias Schulz \& Doris Stolberg (eds.), Sprache und (Post)Kolonialismus, 205-234. Berlin \& Boston: De Gruyter Mouton.

Schulze, Mathias, James M. Skidmore, David G. John, Grit Liebscher \& Sebastian SiebelAchenbach (eds.). 2008. German diasporic experiences: Identity, migration, and loss. Waterloo, ON: Waterloo Centre for German Studies and Wilfrid Laurier University Press.

Spivak, Gayatri Chakravorty. 1985. The Rani of Sirmur: An essay in reading the archives. History and Theory 24(3). 247-272.

Spivak, Gayatri Chakravorty. 1988. Can the subaltern speak? In Cary Nelson \& Lawrence Grossberg (eds.), Marxism and the interpretation of culture, 271-313. Chicago: University of Illinois Press.

Stolberg, Doris. 2017. Historical sociolinguistics in colonial New Guinea: The Rhenish Mission Society in the Astrolabe Bay. Journal of Historical Sociolinguistics 3(1). 55-92.

Stolz, Thomas \& Ingo H. Warnke. 2015. Aspekte der kolonialen und postkolonialen Toponymie unter besonderer Berücksichtigung des deutschen Kolonialismus. In Daniel SchmidtBrücken, Susanne Schuster, Thomas Stolz \& Ingo H. Warnke (eds.), Koloniallinguistik. Sprache in kolonialen Kontexten, 107-175. Berlin \& Boston: De Gruyter Mouton.

Stolz, Thomas \& Ingo H. Warnke (eds.). 2018. Vergleichende Kolonialtoponomastik. Strukturen und Funktionen kolonialer Ortsbenennung. Berlin \& Boston: De Gruyter Mouton. 